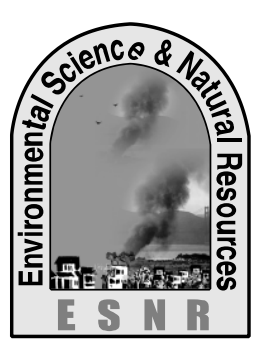

\title{
Soil Nutrient Status of Brahmaputra Floodplain Area in Tangail Sadar Upazila for Agricultural Uses
}

\author{
M. A. M. Hossen, S. A. Lira, M. Y. Mia* and A. K. M. M. Rahman ${ }^{1}$ \\ Department of Environmental Science and Resource Management, \\ Mawlana Bhashani Science and Technology University, Tangail 1902, Bangladesh \\ ${ }^{1}$ Soil Resource Development Institute, Tangail, Bangladesh \\ *Corresponding author: mdmia1998@gmail.com
}

Abstract

Soil samples from high land, medium high land, medium low land and low land of Brahmaputra Floodplain area showed that $\mathrm{pH}$ of the soils were slightly acidic; organic matter $(\mathrm{OM})$ content was medium; total nitrogen $(\mathrm{N})$, available potassium $(\mathrm{K})$ and boron $(\mathrm{B})$ content were low; available phosphorus $(\mathrm{P})$ content was very low; available sulfur $(\mathrm{S})$ and calcium $(\mathrm{Ca})$ content were medium to very high; magnesium $(\mathrm{Mg})$ and zinc $(\mathrm{Zn})$ content were low to optimum; copper $(\mathrm{Cu})$, manganese $(\mathrm{Mn})$ and iron $(\mathrm{Fe})$ content were very high suggesting the fact that soils of this area is moderately suitable for agricultural uses.

Key words: Agricultural uses, Brahmaputra floodplain area, Soil nutrient status

\section{Introduction}

Soil is a natural resource for which there is no substitute. It is a thin covering over the land consisting of a mixture of minerals, organic materials, living organisms, air and water that together support the growth of plant life (Huq and Shoaib, 2013). Because agriculture is a soil-based industry that extracts nutrients from the soil, effective and efficient approaches to slowing that removal and returning nutrients to the soil will be required in order to maintain and increase crop productivity and sustain agriculture for the long term (Brammer, 1986). The Brahmaputra floodplain Area is another top quality agricultural land in Bangladesh for the crop production because of its alluvial and nutrient-rich soil for the crop production. The geographical position and geological causes of siltation makes the land more fertile among the other types of land (Mamun et al., 2011). Cultivation has been made through a few decades, as a result changes in soil quality (SRDI, 2009). So the nutrient status of this soil is important to assess and also maximum crop production have to be assured. But the agricultural land is gradually decreasing due to various natural and anthropogenic activities (Alcantara-Ayala and Goudie, 2010). The agriculture of Bangladesh has been suffering from various problems such as nutrient deficiency and toxicity of soil, natural calamities, insects and disease hazards, improper soil and crop management, alteration of agricultural land by various processes (Abdullah, 1990). Soil pollution adversely effects on agricultural land such as loss of productivity on soil, damage of crop production and most important the effects on soil nutrients (Ahmed et al., 2002). Agricultural production is the main economic activity in our country. So, nutrient status of soil and their suitable maximum crop production should be ensured for better economic development of the country (ADAB News, 1979). Considering these things in mind, the study was conducted in the Brahmaputra floodplain area with the following objectives: (i) to determine nutrient status of Brahmaputra floodplain area and (ii) to compare nutrient status of Brahmaputra floodplain area with Fertilizer Recommendation Guide (FRG) standard for agricultural uses.

\section{Materials and Methods}

\section{Study area}

Brahmaputra floodplain area at Tangail Sadar upazila of Tangail district located in between $24^{\circ} 10^{\prime}$ and $24^{\circ} 22^{\prime}$ North Latitudes and in between $88^{\circ} 46^{\prime}$ and $89^{\circ} 59^{\prime}$ East Longitudes. The study area was divided into four types of land namely high land, medium high land, medium low land and low land. Soil samples were collected from the agricultural land of the above four land types.

\section{Soil sampling}

The samples were collected from the study area within a depth of $15 \mathrm{~cm}$. Total 26 soil samples were collected from seven different areas as Mogra, Baghil, Gala, Gharinda, Tangail Sadar, Danya, and Porabari. The collected soil samples (500 g) were air dried, ground and sieved for analysis.

\section{Sample analysis}

Soil $\mathrm{pH}$ was measured by soil $\mathrm{pH}$ and Moisture Meter. The Organic Matter (OM) content was analyzed Titrimetrically by Walkley and Black's Wet Oxidation method with oxidation of organic matter with potassium dichromate $\left(\mathrm{K}_{2} \mathrm{Cr}_{2} \mathrm{O}_{7}\right)$ (Walkley and Black, 1934). Total $\mathrm{N}$ content of soil was determined by Micro Kjeldahl method. Available phosphorus was extracted from the soil by shaking with $0.03 \mathrm{M} \mathrm{NH}_{4} \mathrm{~F}-0.025 \mathrm{M} \mathrm{HCl}$ solution at $\mathrm{pH}<7.0$ following the method of Bray and Kurtz method. The samples were read with the help of a Spectrophotometer at $660 \mathrm{~nm}$ wave length. Available sulphur was determined by extracting the soil samples by calcium dihydrogen phosphate extraction method. Exchangeable K content was determined with the help of flame emission Spectrophotometer using K filters by ammonium acetate extraction method (Satter et al., 1987). The available calcium (Ca) and magnesium ( $\mathrm{Mg}$ ) contents were extracted by ammonium acetate extraction method and determined by Ethylenediamene Tetra Acetic acid titration. Available zinc ( $\mathrm{Zn}$ ), copper $(\mathrm{Cu})$, manganese $(\mathrm{Mn})$ and iron $(\mathrm{Fe})$ were determined by DTPA extraction method using NOV AA-300 Atomic Absorption Spectrophotometer (Huq and Alam, 2005). Boron (B) content was analyzed according to Hot-water extraction method by dilute calcium chloride solution (Wolf, 1971). 


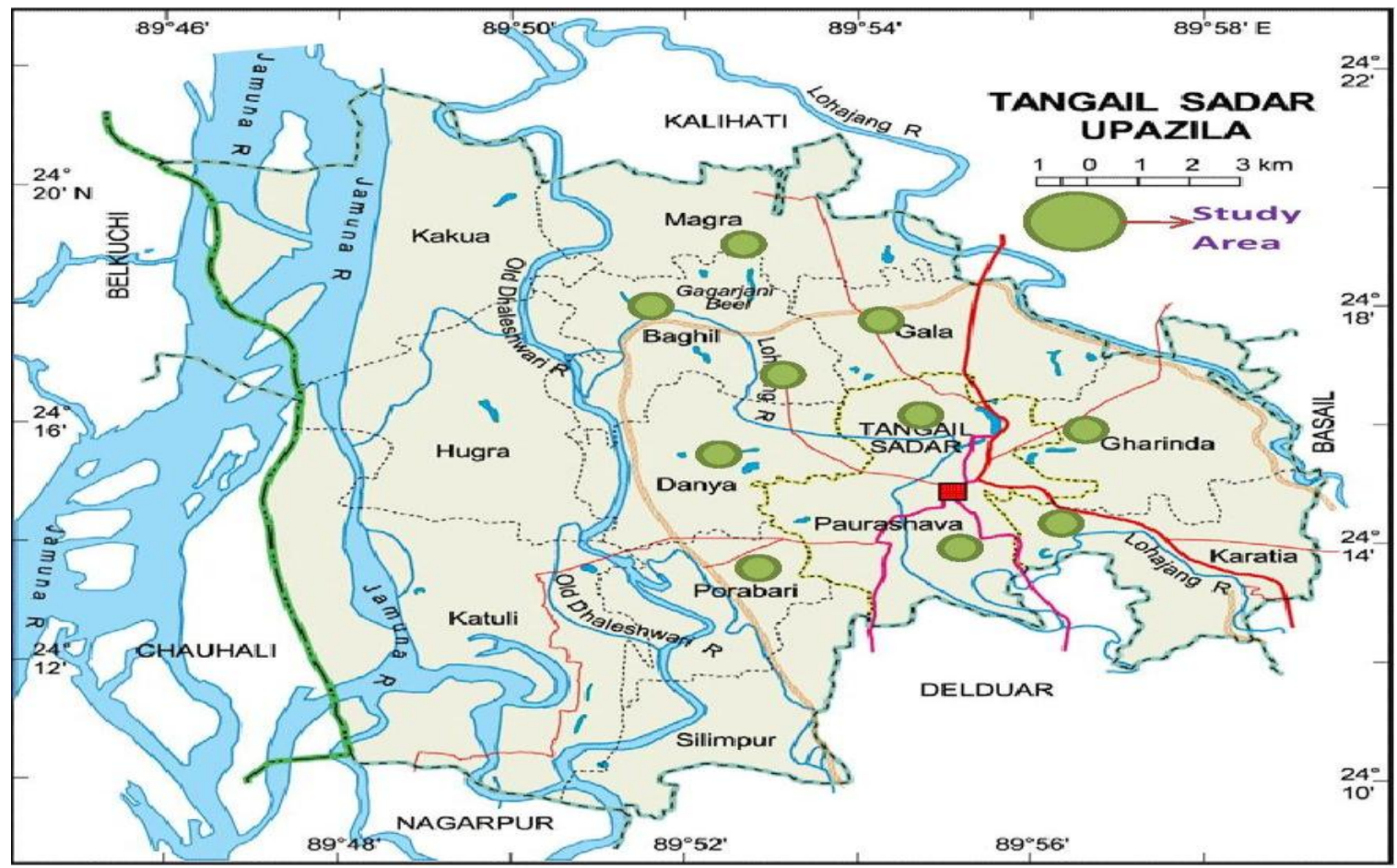

Fig. 1. Map showing the Brahmaputra floodplain area of Tangail Sadar Upazila

\section{Statistical analysis}

The Microsoft Office Excel software was used to present and interpret the collected data.

\section{Results and Discussion}

The optimum soil $\mathrm{pH}$ for crop cultivation is $6.6-7.3$ (FRG, 2012). The investigated $\mathrm{pH}$ values of high land, medium high land, medium low land and low land soils ranged from 5.7 to $6.8,5.3$ to $6.2,5.7$ to 6.2 and 5.6 to 6.1 , respectively with the mean of $6.16( \pm 0.40), 5.7$ $( \pm 0.33), 5.90( \pm 0.21)$ and $5.85( \pm 0.24)$, respectively (Table 1). The mean indicated slightly acidic condition in all collected soils of the investigated area. This might be due to acidic parent materials, oxidation of sulfates and harvest of high-yielding crops.

For agricultural uses suitable organic matter (OM) content in soil is $1.8-3.4 \%$ (FRG, 2012). The OM content ranged from 1.20 to $3.10 \%, 1.27$ to $2.24 \%, 2.17$ to $3.31 \%$ and 1.62 to $3.31 \%$ in high land, medium high land, medium low land and low land soils, respectively with the mean of $2.12 \%( \pm 0.73), 1.80 \%( \pm 0.38), 2.61 \%$ $( \pm 0.43)$ and $2.68 \%( \pm 0.78)$, respectively (Table 1$)$. All soils showed medium OM content. It might be due to excessive tillage and fallowing. The optimum total nitrogen $(\mathrm{N})$ value for agricultural uses is $0.27-0.36 \%$ (FRG, 2012). Total $\mathrm{N}$ content were found from 0.07 to $0.17 \%, 0.07$ to $0.13 \%, 0.14$ to $0.19 \%$ and 0.09 to $0.19 \%$ in high land, medium high land, medium low land and low land, respectively with the average of $0.11 \%$ $( \pm 0.03), 0.10 \%( \pm 0.02), 0.14 \%( \pm 0.03)$ and $0.15 \%$ $( \pm 0.05)$, respectively (Table 1$)$. The total $\mathrm{N}$ content of all soils was low. It could be due to $\mathrm{N}$ availability decreases in acidic condition.

Table 1. Nutrient status of high land, medium high land, medium low land and low land of Tangail Sadar upazila

\begin{tabular}{|c|c|c|c|c|}
\hline Parameters & $\begin{array}{c}\text { High land } \\
(\text { Mean } \pm \text { SD })\end{array}$ & $\begin{array}{c}\text { Medium } \\
\text { High land } \\
(\text { Mean } \pm \text { SD })\end{array}$ & $\begin{array}{c}\text { Medium } \\
\text { low land } \\
(\text { Mean } \pm \mathrm{SD})\end{array}$ & $\begin{array}{c}\text { Low land } \\
(\text { Mean } \pm \text { SD })\end{array}$ \\
\hline $\mathrm{pH}$ & $6.16 \pm 0.40$ & $5.70 \pm 0.33$ & $5.90 \pm 0.21$ & $5.85 \pm 0.24$ \\
\hline $\mathrm{OM}(\%)$ & $2.12 \pm 0.73$ & $1.80 \pm 0.38$ & $2.61 \pm 0.43$ & $2.68 \pm 0.78$ \\
\hline Total N (\%) & $0.11 \pm 0.03$ & $0.10 \pm 0.02$ & $0.14 \pm 0.03$ & $0.15 \pm 0.05$ \\
\hline $\mathrm{P}\left(\mu \mathrm{gg}^{-1}\right.$ soil $)$ & $4.89 \pm 1.93$ & $4.00 \pm 2.39$ & $2.73 \pm 0.63$ & $3.41 \pm 0.72$ \\
\hline $\mathrm{S}\left(\mu \mathrm{gg}^{-1}\right.$ soil $)$ & $18.95 \pm 10.65$ & $27.50 \pm 24.65$ & $32.95 \pm 27.15$ & $42.79 \pm 22.47$ \\
\hline $\mathrm{B}\left(\mu \mathrm{gg}^{-1}\right.$ soil $)$ & $0.17 \pm 0.03$ & $0.20 \pm 0.03$ & $0.19 \pm 0.02$ & $0.18 \pm 0.07$ \\
\hline $\mathrm{Cu}\left(\mu \mathrm{gg}^{-1}\right.$ soil $)$ & $8.51 \pm 4.29$ & $13.00 \pm 7.58$ & $9.00 \pm 2.83$ & $20.25 \pm 5.12$ \\
\hline $\mathrm{Fe}\left(\mu \mathrm{gg}^{-1}\right.$ soil $)$ & $23.13 \pm 3.80$ & $52.10 \pm 24.82$ & $81.40 \pm 12.59$ & $77.50 \pm 3.11$ \\
\hline $\mathrm{Zn}\left(\mu \mathrm{gg}^{-1}\right.$ soil $)$ & $0.75 \pm 0.19$ & $0.70 \pm 0.47$ & $0.83 \pm 0.27$ & $0.94 \pm 0.33$ \\
\hline $\operatorname{Mn}\left(\mu \mathrm{gg}^{-1}\right.$ soil $)$ & $10.75 \pm 2.25$ & $8.40 \pm 3.75$ & $6.80 \pm 3.35$ & $8.75 \pm 1.71$ \\
\hline $\mathrm{K}\left(\mathrm{meqg}^{-100}\right.$ soil $)$ & $0.16 \pm 0.05$ & $0.10 \pm 0.04$ & $0.15 \pm 0.07$ & $0.18 \pm 0.03$ \\
\hline $\mathrm{Ca}\left(\right.$ meqg $^{-100}$ soil $)$ & $3.74 \pm 0.96$ & $4.40 \pm 1.16$ & $8.68 \pm 3.36$ & $4.74 \pm 0.52$ \\
\hline $\operatorname{Mg}\left(\right.$ meqg $^{-100}$ soil $)$ & $0.66 \pm 0.39$ & $0.70 \pm 0.56$ & $0.74 \pm 0.35$ & $1.48 \pm 0.23$ \\
\hline
\end{tabular}


The available phosphorus (P) content 22.51-30 $\mathrm{ggg}^{-1}$ is optimum for agricultural uses (FRG, 2012). Available P

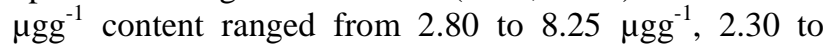
$10.11 \mu \mathrm{gg}^{-1}, 2.14$ to $3.51 \mu \mathrm{gg}^{-1}$ and 2.37 to $3.89 \mu \mathrm{gg}^{-1}$, respectively in high land, medium high land, medium low land and low land with the mean of $4.89( \pm 1.93) \mu^{-1} g^{-1}$, $4.00( \pm 2.39) \mu \mathrm{gg}^{-1}, 2.73( \pm 0.63) \mu \mathrm{gg}^{-1}$ and $3.41( \pm 0.72)$ $\mu \mathrm{gg}^{-1}$, respectively (Table 1 ). The $\mathrm{P}$ content was very low in all soils. This might be due to soil erosion and leaching. The sulphur (S) content 22.51-30 $\mathrm{\mu gg}^{-1}$ is suitable for crop cultivation (FRG, 2012). The range of available $S$ in high land, medium high land, medium low land and low land were from 5.59 to $32.58 \mu \mathrm{gg}^{-1}, 7.50$ to $87.45 \mu \mathrm{gg}^{-1}, 16.57$ to $80.77 \mu \mathrm{gg}^{-1}$ and 19.00 to $63.54 \mu \mathrm{gg}^{-1}$, respectively with the mean of $18.95( \pm 10.65) \mu \mathrm{gg}^{-1}, 27.50( \pm 24.65) \mu \mathrm{gg}^{-1}$, $32.95 \quad( \pm 27.15) \quad \mu g g^{-1}$ and $42.79 \quad( \pm 22.47) \quad \mu g^{-1}$, respectively (Table 1). The $\mathrm{S}$ content in high land soil was medium and the rest were suitable for agricultural uses containing up to very high level of S. It might be due to use of $\mathrm{P}$ fertilizers that contained $\mathrm{S}$ (superphosphates). The optimum boron (B) content for crop cultivation is 0.45-0.6 $\mathrm{ggg}^{-1}$ (FRG, 2012). The B content was recorded from 0.14 to $0.20 \mu \mathrm{gg}^{-1}, 0.14$ to $0.24 \mu \mathrm{gg}^{-1}, 0.16$ to 0.21 $\mu \mathrm{gg}^{-1}$ and 0.11 to $0.25 \mu \mathrm{gg}^{-1}$, respectively in high land, medium high land, medium low land and low land with the average of $0.17( \pm 0.03) \mu \mathrm{gg}^{-1}, 0.20( \pm 0.03) \mu \mathrm{gg}^{-1}, 0.19$ $( \pm 0.02) \mu g^{-1}$ and $0.18( \pm 0.07) \mu g^{-1}$, respectively (Table $1)$. The $B$ content of all soils was low. This could be due to less OM content which is a reservoir for $\mathrm{B}$.

For optimum crop production copper $(\mathrm{Cu})$ content 0.45

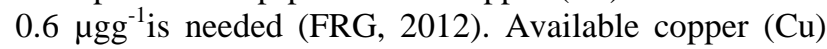
content in soils of high land, medium high land, medium low land and low land ranged from 2.80 to $12.00 \mathrm{\mu gg}^{-1}$, 6.00 to $25.00 \mu \mathrm{gg}^{-1}, 6.00$ to $12.00 \mu \mathrm{gg}^{-1}$ and 13.00 to 25.00 $\mu \mathrm{gg}^{-1}$, respectively with the mean of $8.51( \pm 4.29) \mu \mathrm{gg}^{-1}$,

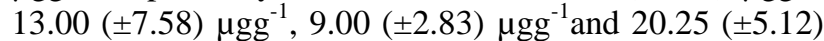
$\mu \mathrm{gg}^{-1}$, respectively (Table 1 ). The $\mathrm{Cu}$ content of all soils were very high. It might be due to acidic condition of soils. The suitable iron (Fe) content for crop cultivation is 9.1 to $12 \mu \mathrm{gg}^{-1}$ (FRG, 2012). Fe content was at very high level in high land, medium high land, medium low land and low land ranging from 18.00 to $28.00 \mu \mathrm{gg}^{-1}, 20.00$ to $81.00 \mu \mathrm{gg}^{-1}, 21.00$ to $56.00 \mu \mathrm{gg}^{-1}$ and 74.00 to $81.00 \mu \mathrm{gg}^{-1}$, respectively with the average of $23.13( \pm 3.80) \mu^{-1} g^{-1}$, $52.10( \pm 24.82) \mu^{2} g^{-1}, 81.40( \pm 12.58) \mu^{2} g^{-1}$ and 77.50 $( \pm 3.11) \mu \mathrm{gg}^{-1}$, respectively (Table 1 ). The Fe content of all soils was very high. This could be due to zinc deficiency in all soils. The zinc $(\mathrm{Zn})$ content 1.35 to 1.8 $\mu \mathrm{gg}^{-1}$ is suitable for agricultural uses (FRG, 2012). Total

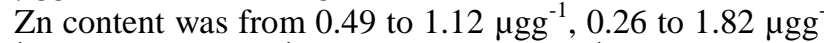
${ }^{1}, 0.66$ to $1.30 \mu \mathrm{gg}^{-1}$ and 0.72 to $1.42 \mu \mathrm{gg}^{-1}$, respectively in high land, medium high land, medium low land and low land with the mean of $0.75( \pm 0.19) \mu \mathrm{gg}^{-1}, 0.70( \pm 0.47)$ $\mu g^{-1}, \quad 0.83 \mu \operatorname{sg}^{-1}( \pm 0.27)$ and $0.94 \quad( \pm 0.33) \mu g g^{-1}$, respectively (Table 1). Except low land soils which contained medium level of $\mathrm{Zn}$ all other soils containedlow $\mathrm{Zn}$. This could be due to high manganese level in all soils.The optimum manganese (Mn) content for crop cultivation is $2.25-3 \mu^{-1}$ (FRG, 2012). The Mn content of high land, medium high land, medium low land and low land soils ranged from 7.00 to $13.00 \mu \mathrm{gg}^{-1}, 2.00$ to $13.00 \mu \mathrm{gg}^{-1}, 4.00$ to $12.00 \mu \mathrm{gg}^{-1}$ and 7.00 to $11.00 \mu \mathrm{gg}^{-1}$, respectively with the mean of $10.75( \pm 2.75), 8.4( \pm 3.75)$

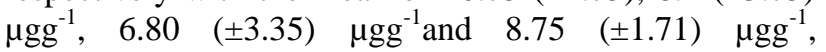
respectively (Table 1$)$. All soils represented very high level of Mn than the optimum value. This could be due to high nitrogen or phosphorus applications on acidic, low organic matter soils. The available potassium $(\mathrm{K})$ value $0.27-0.36$ meqg $^{-100}$ soil is suitable for agricultural uses (FRG, 2012). Total K content of high land, medium high land, medium low land and low land was from 0.08 to 0.22 meqg $^{-100}, 0.06$ to 0.18 meqg $^{-100}, 0.11$ to $0.27 \mathrm{meqg}^{-}$ ${ }^{100}$ and 0.15 to 0.21 meqg $^{-100}$, respectively with the mean of $0.16( \pm 0.05) \mathrm{meqg}^{-100}, 0.10( \pm 0.04) \mathrm{meqg}^{-100}, 0.15$ $( \pm 0.07)$ meqg $^{-100}$ and $0.18( \pm 0.03)$ meqg $^{-100}$, respectively (Table 1). The mean indicated low $\mathrm{K}$ content in all soils that was not suitable for agricultural uses. This could be due to high nitrogen fertilizer application for increasing yield.

The available calcium (Ca) content $4.5-6.0$ meqg $^{-100}$ is suitable for agricultural uses (FRG, 2012). Total Ca content were found within the range of 3.10 to $6.01 \mathrm{meqg}^{-}$ ${ }^{100}, 2.90$ to 6.50 meqg $^{-100}, 4.60$ to 22.60 meqg $^{-100}$ and 4.27 to 5.40 meqg $^{-100}$, respectively in high land, medium high land, medium low land and low land with the mean of $3.74( \pm 0.96) \mathrm{meqg}^{-100}, 4.40( \pm 1.16) \mathrm{meqg}^{-100}, 8.68( \pm 7.80)$ meqg ${ }^{-100}$ and $4.74( \pm 0.52)$ meqg $^{-100}$, respectively (Table 1$)$. The Ca content in high land soil was medium and the rest were suitable for agricultural uses containing up to very high level of $\mathrm{Ca}$. It might be due to heavy application of potassium fertilizers.

The magnesium $(\mathrm{Mg})$ content $1.12-1.5 \mathrm{meqg}^{-100}$ soil is suitable for agricultural uses (FRG, 2012). The $\mathrm{Mg}$ content ranged from 0.28 to 1.47 meqg $^{-100}, 0.08$ to 1.70 meqg $^{-100}, 0.17$ to 1.08 meqg $^{-100}$ and 1.10 to 1.75 meqg $^{-100}$, respectively in high land, medium high land, medium low land and low land with the respective mean of 0.66 $( \pm 0.39)$ meqg $^{-100}, 0.70( \pm 0.56)$ meqg $^{-100}, 0.74( \pm 0.35)$ meqg $^{-100}$ and $1.48( \pm 0.23)$ (Table 1). Except low land soils which contained optimum $\mathrm{Mg}$ content, all soils represent low $\mathrm{Mg}$ value. This could be due to high nitrogen fertilizer application for increasing yield.

To maintain soil quality for agricultural uses it is needed to take necessary initiatives against soil erosion, improper and excessive use of fertilizers and pesticides and excessive tillage etc. Soils should be tested on a regular basis to determine its conditions and scientists should consult farmers about proper use of fertilizers.

\section{Conclusions}

The study concluded that $\mathrm{pH}$ of the soils of Brahmaputra floodplain area was slightly acidic. The total $\mathrm{N}$, available $\mathrm{P}, \mathrm{K}, \mathrm{Mg}$ and $\mathrm{Zn}$ content of the soils were unsuitable for agricultural uses. The OM content was moderately suitable for agricultural uses. Only total $\mathrm{Ca}$ and $\mathrm{S}$ content were suitable for crop production. But $\mathrm{Mn}, \mathrm{Fe}$ and $\mathrm{Cu}$ 
content were at very high level, which may reduce crop production. Overall soils of Brahmaputra floodplain area were moderately suitable for agricultural uses.

\section{Acknowledgements}

The authors express their sincere gratitude to the scientists of Soil Resource Development Institute (SRDI) for their help during the study period.

\section{References}

Abdullah, A. 1990. Recent Performance and Evaluation of Policies in Agriculture. A Report Prepared for the World Bank Resident Mission, Dhaka: BIDS.

ADAB News, 1979. Agricultural Development Agencies in Bangladesh, Dhaka.

Ahmed, N., Varadachari, C. and Ghosh, K. 2002. Soil clay-humus complexes I, alkali dissolution, TEM and XRD studies. Australian Journal of Soil Research, 40:691-703.

Alcantara-Ayala, I. and Goudie, A. 2010. Geomorphological Hazards and Disaster Prevention. Cambridge University Press, New York, 180p.

Brammer, H. 1986. Classification of the soils of Bangladesh in the legend for the FAO/UNESCO soil map of the world. Soil Resources Development Institute, Dhaka, 222p.

FRG. 2012. Fertilizer Recommendation Guide. Soils publication no. 41, Bangladesh Agricultural Research Council (BARC), Farmgate, Dhaka 1215, pp. 251-253.

Huq S. M. I. and Shoaib, J. U. M., 2013. The soils of Bangladesh. Worlds Soil Book Series 1, DOI: 10, 1007/978-94-007 $128-0$.

Huq, S. M. I. and Alam, M. D. 2005. A Handbook on Analysis of Soil, Plant and Water. BACER-DU. University of Dhaka, Bangladesh, 246p.
Huq, S. M. I. and Shoaib, J. U. M. 2013. The soils of Bangladesh. Worlds Soil Book Series 1, DOI: 10, 1007/978-94-007-128-0.

Imam, S. M. H. and Didar, M. A. (eds.). 2005. A handbook on analysis of soil, plant and water. Bangladesh-Australia Centre for Environmental Research (BACER-DU), Dhaka, pp. 31-40.

Jackson, M. L. 1973. Soil Chemical Analysis. Prentice Hall of India, Pvt. Ltd, 498p.

Mamun, S. A., Rahman, F., Yeasmin F. and Islam, M. A., 2011. Suitability of the Physical Properties of Soil for Crop Production. A Study in Tangail Sadar. Journal of Environmental Science and Natural Resources, 4(2): 121-125.

Satter, D. M. A. and Rahman, M. M. 1987. Techniques of Soil Analysis. Department of Soil Science, Bangladesh Agricultural University, Mymensingh, pp. 67-124.

SRDI. 2009. Land and soil resources Utilization Guide (In Bengali). Upazila Nirdeshica Series-Tangail Sadar, Soil Resources Development Institute, Dhaka.

Walkley, A. J. and Black, I. A. 1934. Estimation of soil organic carbon by the chromic acid titration method. Soil Science, 37: 29-38.

Wolf, B. 1971. The determination of boron in soil extracts, plant materials, composts, manures, water and nutrient solutions. Soil Science Plant Analysis, 2: 363-374. 